\title{
LANGUAGE IMAGERIES/SYMBOLS UTTERED BY KING LEAR HIMSELF IN KING LEAR TRAGEDY
}

\author{
Mangantar Sitohang \\ STIBA IEC Jakarta \\ mangantar@stibaiec-jakarta.ac.id
}

\begin{abstract}
This research attempts to analyze Shakespeare language symbols/imagery in King Lear (Tragedy Drama). It is generally agreed that there are always many factors why a playwright is still remembered from a century to next centuries, and among many factors that could make someone always well-known/remembered is his/her language factor beside the theme or the messages s/he wanted to convey, of course. King Lear had succeeded to choose the right rhetoric devices or signs in his period and wonder many people are still amazed / inspired up to now due to his unique and rich language. His symbols / imagery, combined with verse and prose in King Lear can express penetratingly the essence of a thing, emotion or situation in term of another, thus convey the sharpness of one's own vision and sensitivity one's reader or spectator, again the imagery / symbol here, are connected aspects or angles of people's lives, and all are interwoven beautifully, and again it's the language quality of King Lear that makes the researcher is tempted to observe it.
\end{abstract}

Key words: language symbols, imagery, playwright, intellectual experience, interwoven beautifully.

\section{A. INTRODUCTION}

\section{Background}

Among many world class/great playwrights, Shakespeare is the only one labelled as the greatest plyawright, As Martin Lings said " Shakespeare has been defined more than once as ' the most famous writer in the world'. Admittedly, fame does not coincide with execellence; but he is by common concent- we migth even say international consent- a dramatist who has never been surpassed " (The Secret of Shakespeare). 
Even though he was born many centuries ago, he is still recognised / known as the greatest playwright in England and in the world up to now (Samekto, SS,MA. page 21 1986).

His works are still popular up to present, that's because of his brilliant style to write very rich themes and issues and to show interesting techniques in Characterisation, Structure, Imagery and Verse and Prose in almost all his works, and his works still can be enjoyed by his readers / listeners or moviegoers.

The form of his work is unique and incomparable, impaired by faults as brilliant as the colours in the golden pheasant's plumage. He was afflicted by all the diseases of style proper to his age, one after another, as well as by it's happy bravery, and blended them in a style entirely his own, which transforms it's constituent elements and harmonizes disparaties as numerous though they had been assembled in each play in fulfillment of a wager. (History of English Literature, Legouis \&Cazamian's 1957: 435)

Shakespeare is like food, we take very much for granted. It is only when we come across a passage of a particular intensity in a play that we question how that language has been employed to achieve the result, just as it is for exotic dishes that we enquire about the ingredients. To many, therefore Shakespeare may well seem more familiar than most modern dramatists. This situation is accentuated by the assimilation of so many Shakespearean expressions in our daily language (N.F.Blake, $1989: 7$ ). So his language style to impress and entertain his readers is beautifull and unique, and up to the present many famous quotations from him are popular and inspiring to us, such as; What's in a name? That which we call arose . Parting is such a sweet sorrow. All that glitters is not gold. To be or not to be. The course of true love never did run smooth, Take her or leave her, Although the last but but not the least (the last two taken from King Lear) The above Shakespeare's sayings are are really refreshing and easy to remember and they are eternal even though they were created hundreds years ago. 
In King Lear, Shakespeare always displays the magnificent range of his linguistic power and linguistic richness, and they are almost inexhaustible and King Lear itself contains some of the highest peak of Shakespeare's poetic art, and as a result his words often contain many connotations. In short the language found is diverse and alive. So the researcher is curious to investigate and reveal how Shakespeare shows the diversities of his language in King Lear and to convey his exact and alive message in the right context.

As mentioned previously that much of Shakespeare's fame or popularity up to now is much influenced or colored by his language style that makes almost all his works are still memorable and King Lear is without exception. Again, Shakespeare's language diversities and richness found in King Lear are very rich or colorful, and to mention some such as; poetic and verse elements, register (language variety) and symbolism/imagery. And researchers only focus in this investigation, deals with symbolism/imagery, as symbolism/imagery itself has many types/kinds and also has slippery references in real life situation. So in King Lear, the presence of symbolism/imagery can often express penetratingly the essence of a thing, emotion or situation in terms of another, and thus to convey the sharpness of one's vision and sensitivity to his/her target audience. And this play has the vibrant web of imagery which makes story becomes compelling, dark, harsh, and disturbing, as the readers / audience are also challenged to grab both denotative messages and connotative messages as well.

Their uses in the play are to portray the characters habit or personality and again the presence of imagery certainly describes ideas and object aptly but at the same time, it gives special effect or emphasis and their messages can be slippery at the same time also entertaining. Actually almost the characters in this play use/utter many imageries/symbols, but researcher just focuses the symbols used/uttered by Lear, as His tragedy becomes the main the theme of this play. 


\section{The Objectives}

Based on the background above, the objectives of this study are to find out the symbols/imageries which are used in King Lear used by King Lear Himself and to find out what emotions the symbols signify.

\section{Theoretical Framework}

The old literary works language characteristics are more unique, such as in King Lear than the more up-to -date ones. Their uniqueness is so abundant so it needs some techniques or approaches to make it more clear, especially dealing with imagery/language symbols meaning analysis, so here the researcher would first see language symbol analysis perspectives from some inter related disciplines.

\subsection{Stylistics.}

One way of relating language with literature is through Stylistics, which H. G. Widdowson has described as being an area of mediation between two disciplines. The disciplines that he refers to are those of linguistics and literary criticism and Widdowson explains the link between linguistics and language, on the one hand, and literary criticism on the other in the form of a diagram.

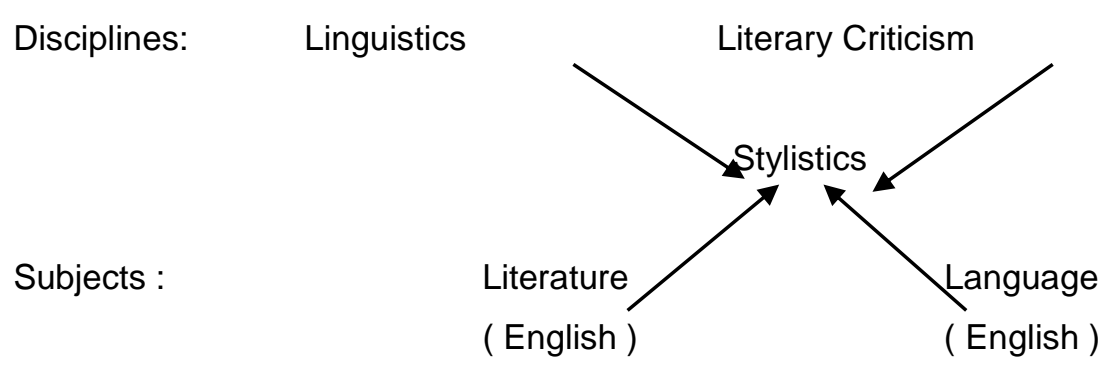

The above frame by Widdowson wants to show us that Stylistics is neither a discipline nor is it a subject. The diagram shows that Stylistics can not only facilitate literature and language as subjects to move both linguistics and literary criticism but can also provide for the progression of toward a 
student better comprehension and appreciation of literature. So it can be paraphrased, that Stylistics, a method of textual interpretation in which of place is assigned to language uses, and the purpose of stylistics is to explore/investigate the language, and more specifically, to explore/investigate creativity language uses or phenomenon especially in literary texts. (Paul Simpson, $2004: 3)$

\subsection{Meaning perspectives}

From Semantics angle, meaning perspectives partly can be observed from three layers, they are reference, denotative and connotative meanings. Reference is the relation between a language expression and whatever expression pertains to it in a particular situation of language use, including what a speaker may imagine. Denotation identifies the central aspect of a meaning which everybody generally agrees about, while connotation refers to the personal aspect of meaning, the emotional association that the arouses. Connotations vary according to the experience of individuals but, because people do have common experience, some words have shared connotations. And it is widely agreed that connotation meaning will have to do both emotional and personal meanings/messages

\subsubsection{Semiotics, Signifier and Signified}

The process of creating and interpreting symbols, sometimes called signification which is far wider than language, Scholars like Ferdinand de Saussure (1974) have stressed that the study of linguistic meaning is part of this general study of the use of the sign system, and this general study is called semiotics. Semioticians investigate the type of relationship that may hold between sign and the object it represents, or, in de Saussure terminology between a signifier and it's signified.

The following is Ferdinand de Saussure's semiotic triangle showing the theory of indirect relationship of reference 
Thought (concept)

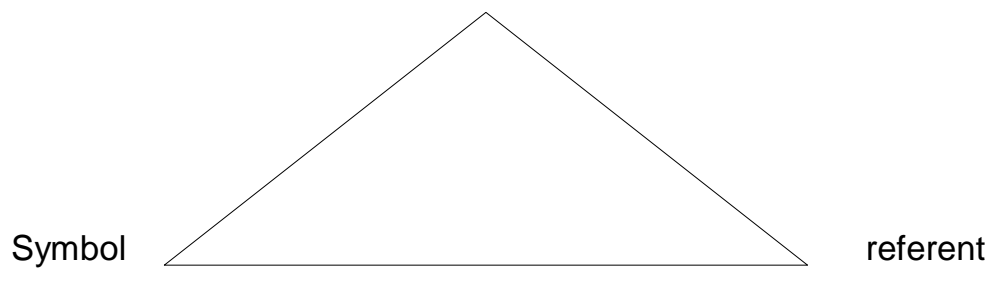

3.2.2. Reference and denotation.

In every language there are words like tree and run and red which seems to have an obvious relation to objects and events and description of the things in the world around us. We are likely to think that a language consists of a large number of words and each these words has a direct correlation with something outside of a language which is its meaning. And if we communicate with one another through language, it must be that we all have the same 'idea' or 'concept' associated with each word. And according to Charles W. Kreider, the best known elaboration of this view was made by Odgen and Richard (1923) who developed a mentalistic theory about meaning, an attempt to explain meaning in term of what is in people's mind. Their explanation centers around this scheme:

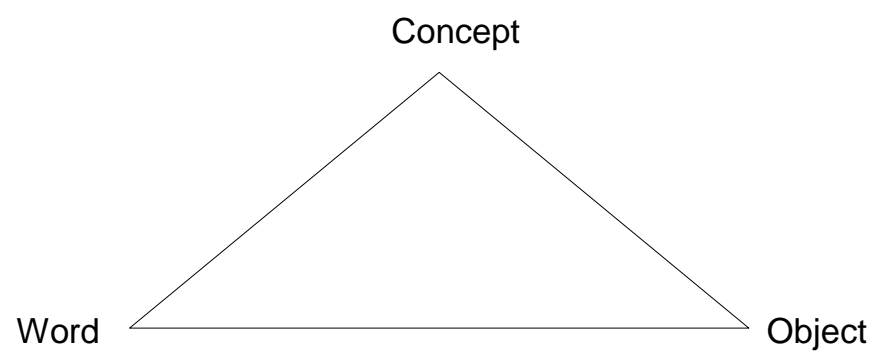

Odgen and Richard called the bond between word and the concept an 'association' the bond between concept and object 'reference', and the bond between object and word 'meaning'.

\subsection{Imagery Language.}

Imagery, as literary term is difficult to describe with precision, because the way it is used is often loosely, but according to Richard, 1997: 173 Imagery 
language is words or sentences that produce strong picture-like images may be easier to remember than those without visual imaginary. So in broad sense, it can be used to describe any writing which is descriptive, and help the readers to visualize a scene and to experience a playwright's experience.

But basic essence of imagery is to create a particular picture in readers / audience's mind. And the most condensed form of imagery can be found in figures of speech, although not all figures of speech involve imagery. Another form imagery is in the use of symbolism. Symbolism is a use of a language in which an image represent something, by the presence of symbolism word or words / sentence can evoke the meaning into more colorful or stronger effects. In King Lear both symbolism and imagery become important parts/elements in almost in every act and scene, and these elements are perhaps King Lear's icon, and make it as Shakespeare's greatest works.

\subsection{Methodology}

In this observation, the researcher uses descriptive discourse analysis to describe the theories related to this research topic.

\section{Methodology}

This study aimed to get the understanding about the symbols/imageries which are used in King Lear used by King Lear Himself and what emotions the symbols signify. Research methodology used is a qualitative method

\section{B. FINDING AND DISCUSSION}

Before the researcher attempts to reveal the presence of the imageries/symbols in King Lear, the researcher would like to tell at glance the tragedy of King Lear, more especially in relation with the uses of symbols/imageries, and this following is the very brief summary; "Realizing that $\mathrm{He}$ is no more young, King Lear plan to inherit his Kingdom into three parts, as He has three children (daughters), they are Goneril ( the first daughter), Regan ( the second) and the third and King Lear's most favorite among the three, and 
before the King Himself announced his total authority about the division of His Kingdom to his daughters, He demanded to hear/listen about his daughters' commitment for the King publicly/openly when he retired, the first two daughters, Goneril and Regan very successfully pleased their father by giving very beautiful words/promises, and the following Goneril's reply to King's demand:

Sir, I love you more than word can wield the matter:

Dearer than eyesight, space and liberty;

Beyond what can be valued, rich or rare... (1.1. 52-55 )

Having listened to Goneril's flattery beautiful pledge (promise), Lear is very satisfied and happy and He gives Goneril's portion as already planned.

The second daughter, Regan gives no different flattering verse forms, and a bit longer, hoping to get more attention from the King.

Regan :

I am made of that self metal as my sister,

And prize me at her worth, in $\boldsymbol{m} y$ true heart

I find she names my very deed of love;

Only she comes too short: that I profess...

...I am alone felicitate

In your dear highness' love. (1.1.65-70).

When demanding the open commitment from his most favorite daughter, Cordelia, She simply responds

Cordelia answers: Nothing, my Lord.

Lear: Nothing?

Cordelia: Nothing.

Lear: Nothing will come of nothing: speak again.

Cordelia: Unhappy that I am, I cannot heave

My heart into my mouth: I love your majesty 
According to my bond; no more no less...( 1.1 .87 $90)$.

Upon hearing his favorite reply, that is totally different from hope/expectation King is upset and furious, and the King final decision is not to divide his kingdom into three but just for Goneril and Regan and Cordelia gets nothing. The King even let someone, King of France marry Cordelia without any dowry and he also curses his own daughter. Both Goneril and Regan are very happy of their misjudgment for his transfer of power. To them, the transfer of power is not total yet as the King still keeps half his knights under his control and Goneril and Regan question about their insincere stance. They both want to have all the knights from their father, but their father reject ,and then Goneril and Regan send their knights to attack the King's knights and the is defeated even thought is already helped King of France so at last the king becomes homeless as, Goneril and Regan don't let their father stay with them in turns as the King once hoped before giving his power to them. At last King realized his abundant mistakes, the first two daughters are heartless to their father, beside they also illicit lover for the man called Edmund and of course these are the triggers of all symbols/imageries presence. So mostly it is the King who articulates the symbols and the same time, it is for Goneril and Regan, the symbols are addressed to.

Actually, there are some other characters who use/articulate symbols or who get those symbols in King Lear but the researcher's focus is to Lear who articulates the symbols and his three daughters to whom the symbols are addressed. Disappointed by his favorite daughter reply, the king is furious, then he swears Cordelia by saying

\section{1-3. "For, by the sacred radiance of the sun, the mysteries of Hecate, and} the night, by all the operation of the robs" ( I,I.105-107)1. Sun denotes to one the galaxies that gives light or warm to the earth, while connotatively relates strong passion, Here Lear also swears that his ties with Cordelia are broken, and mysteries source of nature that he mentions represent his passion in revolt against, and the mysteries of hecate denotes the rites of the goddess 
with the darkness of night and the operation of the rob , According to astrology this denotes the position of the body that determine or indicate somebody's fate in the future. And in one occasion when one of his loyal men reminded him to think more clearly to his daughter Cordelia, so he could stop his rage, then king answer arrogantly

4. "Come not between the Dragon and his wrath" (I, $\mathrm{i}, 117)$. Seen connotative angle, this has to do with very personal and emotional condition, showing arrogance or confidence.

The use of dragon shows the denotation great power and viciousness as dragon is known as a most powerful monster in myth. So, Lear thinks himself as a man who is capable of causing terrible disaster, So the possible referent is what illogical tempramental aging person is.

5. He says "The bow is bent and drawn; make from the shaft" . ( I.i. 138). It means he does not any one to interfere he intended to do to his daughter and Lear realizes Goneril's rudeness and inhumanity to himself, then He utters

6. "...she may feel How sharper than a serpent's tooth it is to have a thankless child!..." (I, iv, 273 - 274). Seen from denotative aspect, serpent is one of the poisonous snakes having very sharp and connotatively refers Lear's has curse toward Goneril to be childless and if it is not, she would be present with a child that gives burden to her all life. Other possible message, that Goneril is the thankless child and the cause she made to her father is much more painful than a serpent's bite. As a serpent's bite may kill at once, but what more can be worse than death, beside the great pain and suffering one must endure which made one longed for death. This is how Goneril is being portrayed, the cause of suffering worse than death itself. Lear's words are symbol of great rage, anger and frustration./

7."Sharp-toothed unkindnesslike a vulture..." (II, iv, 130), is what Lear told Regan of her sister Goneril is like the ferocious bird that feeds on flesh. Lear is indicating of Goneril's cruelty on him which he explained as though Goneril feeds on Lear's heart. This is just really indicating that Goneril has made an action of banishing Lear out of her castle and causes the man to feel hurt by his 
daughter's craziest deed. The next symbol Lear attaches to Goneril and Regan is

8. 'Pelican daughters' (III, iv, 73). Denotatively, pelican, type of bird, when young lings would peck their parents during feeding time and it is thought that the young lings attack their parent in order to feed on its parent's flesh and blood. Connotatively, this refers to, that Goneril and Regan's action in banishing away their own father after gaining what they wanted from him. They peck him hard that could eventually lead to his senility and in powerless degree.

Then knowing that her father is badly treated and homeless by her two sisters, she show her anger about the clothes the Lear wears. In King Lear clothes are predominantly used as signs of social identity, meaning they often become central emblem or symbol in the language of the play and very often can show status, prestige and conditions of the wearers. Cordelia shows her anger about the clothes her father wears:

9. Crown'd with rank fumiter and furrow-weeds these denote flowers that are to leader/king's head in the ceremony or they are bitter smell flower.

10. With hardokes, hemlock, nettles, cuckoo-flowers, these also denote type of flower growing ploughed lands

11. And all the idle weeds that grow this refers to flowers that don't grow well / healthily as they normally grow among other plants

12. In our sustaining corn. Refers to kinds of plants that could provide source of food like bread, cookies or flour (IV.iv.3-6).

The above words are deliberate mockery of kingship (Lear himself is crowned with weeds). This is the sign or symbol that shows a very real shameful appearance of order or condition in society. This should happen, when his daughters baished him. And till about clothes, Lear's words are;

Robbes and furr'd gowns hide all. Plate sin with gold,

And the strong lance of justice hurtles breaks;

Arm it in rages, a pigmy's straw does pierce. (IV. vi.158-161).

Lear's critics or judgement, 'Robes and furr'd gowns' or plating of 'gold', meaning from outer appearance, they show expensive price clothes, as only the rich can afford, besides they also function to hide or cover all their hypocricy 
or true identity, that people may misjudge the wearers, and of course this can create problems. Realizing his condition due his own misjudgement, ( V.iii. 304 ) Lear asks himself “

13. "Why should a dog, a horse, a rat, have life?" He quetions himself why Cordelia should be dead so soon, She was killed by unheartedman and this is perhaps the peak of his terrible suffering. To him the basest animals are much more needed that he himself, as he has made some stupid mistakes and lost his favorite daughter who gives him genuine attention / care. Before the death of her favorite daughter, Cordelia, Lear says to her; (V.iii.10-14).

14 . " Come, let's away to prison, we two alone will sing like birds in the cage. The cage refers to the bird's house, but this can be associated with prison, or opportunity to have reconciliation When thou dost ask me blessing, l'll kneel down and thee forgiveness, so we will live, and pray, and sing, and tell the tales and laugh

15. at gilded butterflies, , refer to butterflies that are colorful and beautiful, but this may also have association with people who are beautifully dressed courtiers.

16. and hear poor rogues. Refers to the needy and sinned people but can also have other connotation like injustices or discrimination

Kinds of symbol/imagery uttered by Lear.

From the above shown facts, Lear's language symbols present in the play can be categorized/classified as follows;

1 Nature symbol / imagery. 1-3

2 Animal symbol / imagery. 4, 6,7,8,9,10,11.

3. Tool symbol / imagery.5.

4. Clothes symbol. 9,10,11,12.

Additional symbol analysis

1.1. Sun in the play context, has to do with self-confidence or self-ruled character/selfishness of an old man. At the same time, this can also reflect some personal/emotional associations such as giving light, warmth, heat, 
brightness or clearness, authority so sun does not refers to one of the plants but have many personal /emotional connotation.

2.4.Dragon refers to an imagery fire-breathing animal/ bid monster animal which is very powerful and vicious that can cause great disaster/damage.

But at the same time this can signify arrogant and confident character or arrogance and carelessness an old man/king, (in King Lear context).

2. 6. "...she may feel How sharper than a serpent's tooth it is to have a thankless child!..." This sign/symbol can refer and signify fearful , pitiful feeling and great suffering of an old man that makes his life very terrible, or his sweet and beautiful dreams become great disaster to his life

2.7."Sharp-toothed unkindnesslike a vulture..." This symbol still refers to animal-like daughter behaviour to their father who is getting old. Other possible association to the above symbol ; total forgetfulness, unthankful and brutal. . sister Goneril is like the ferocious bird that feeds on flesh. Lear is indicating of Goneril's cruelty on him which he explained as though Goneril feeds on Lear's heart. This is just really indicating that Goneril has made an action of banishing Lear out of her castle and causes the man to feel hurt by his daughter's craziest deed.

2.8. 'Pelican daughters' can refer to heartless person to their parents as a result makes their parents in terrible life. Realizing his condition due his own misjudgment,

2.9. Why should a dog, a horse, a rat, have life?" Possible association from this symbol, is early/unpredictable death, great regret caused by age, stupidity or misjudgment, or animals are more needed than he himself.

2.10. " Come, let's away to prison, we two alone will sing like birds in the cage this symbol may refer to life that can give value to others or life that is already guaranteed and /or life having limited freedom.

2. 11. at gilded butterflies, signify beauties, arts, entertainment or values to others

2. 12. and hear poor rogues possible association is dishonesty, bad temper and punishment. 
3.5. "The bow is bent and drawn ; make from the shaft" . this can signify carelessness, unalertness or making hasty decision that can not be rewithdrawn or something that is already done but impossible to change.

4.9.10,11,12. 9. Crown'd with rank fumiter and furrow-weeds, 10. With hardokes, hemlock, nettles, cuckoo-flowers,.11. and all the idle weeds that grow.12. In our sustaining corn. These signs/symbols are associated with deliberate mockery of kingship or a very real shameful appearance of order or condition in society or belittling the king status

\section{Symbols used.}

The dominant symbols present in King Lear and uttered by Lear himself is animal/imagery symbols and mostly their the presence show people's characters/ bad had habits which have arrogance, cruelty, selfishness, brutality, evil act sadness and regret. And all these bad / wild animal- behaviors bring / cause disaster /suffering or tragedy to people.

\section{Meaning change and extension of animal symbols}

All animals used in imagery context, refer / show their negative connotations or associations,( pelican bird feeds fish, serpent is a large poisous snake also called as devil snake almost all other animals) while in reality, they were (are) present in our lives giving some beneficial aspects or inspirations such as; bravery, perseverance, endurance etc, so seen from semantic change, their uses can be classified as;

-Perjoration, part of the semantic change that requires negative sense, as the presence animal symbol/sign and clothes symbol seen from negative angles both from personal and emotional aspects

-Narrowing, part of the semantic change where by a word goes from a general sense to a more specific one, animal and clothes symbols can be seen from specific situation both personally and emotionally. So all animals used in symbol / imagery context show the likeliness of human behaviour or characters with those 
beasts, and it leads into suffering or tragedy and clothes for status/condition /prestige or facts.

\section{Signifier and Signified related with animals}

As also mentioned on the earlier part, that structure of the language ( to Ferdinand de Saussure's version) is always related with signifier and signified. So in relation with symbol / imagery, it also has to do with material aspect (signifier) and idea or concept (signified). These two can never be seperated, meaning when there is signifier, there will be also signified, and the meaning or concept (idea) is often arbitrary, as time, situation, interlocutors etc, become important factors, and yet there is no intrinsic/direct relation between sign/symbol with the signified, in other words their relation is also arbitrary.

Again mentioned also in previous parts that Odgen and Richard said, there is also relation the bond between word ( sign/symbol) and the concept an 'association' the bond between concept and object 'reference', and the bond between object and word 'meaning'. The relation between words (signs/symbols) and the associations can be personal/emotional. The emotions might have to do with surprises, arrogance, confidence, rages/anger, sadness, regret as shown in the above parts..

\section{Emotion condition revealed}

Lear at the beginning feels confident in proclaiming the division or transfer of his kingdom to his three daughters, meaning Lear plans to inherit his kingdom, but one of his daughter, Cordelia could not declare very sweet promises before the public, like her daughters, King Lear showed his madness and arrogance that he decided to disinherit her and He inherits only to Goneril and to Regan and Cordelia gets nothing as Lear feels his is still powerful. When getting inhuman treatment from Goneril and Regan, Lear is shy, disappointed and furious as their promises are totally empty that $\mathrm{He}$ curses them by labelling with animal-like behavior daughters, and realizing that he made misjudgment to his daughters, he has great regrets, especially to Cordelia, as she still always shows good respect to her father even though she gets nothing and even constantly gives full supports during her 
father sufferings before her death. In short, unalertness, misjudgments, rage, madness, arrogance, hatred selfishness, shame, disappointment, frustrations and great regret all are the emotions shown the symbol/imagery presence from Lear's utterances.

\section{CONCLUSION}

The symbol / imagery used in the play, function to describe the 'image idea' added to the literal idea. Images work to produce an immediate dramatic effect, such as conveying the characters emotions vividly to the audience. Images recur within the play, and occur within the a context of other imagery often closely comparable or structurally related. And they often recur in a modified form, or by appearing in ironic and unexpected context meaning the 'image-idea' is not static, therefore, it can have a developing new messages. Many images suggest that the characters externalise personal qualities, attributed non- human traits. And last but not least, symbol / imagery helps the readers to see the universe as an enlargement of personal experience. These are parts of Shakespeare genius creativity in creating artistic and beautiful language that can be enjoyed up to now, $\mathrm{He}$ often conveys his messages not literally but with his own language uniqueness that makes his works well-remembered and King Lear is with exception and if his fame fades away . 


\section{REFERENCES}

Akmajian, Adrian dkk; Semantics - Introduction to Language and Communication; London; The MIT Press; 1990.

Aitchison, Jean; Linguistics; London; Teach Yourself; 2003.

Amstrong, Katherine and Graham Atkin; Studying Shakespeare, A Practical Guide; Europe; Prentice Hall; 1998.

Bangh, Alberth C., Thomas Cable, Routledge and Kegan Paul; A History of the English Language Third Edition; London; Glenley; 1978.

Bernard; New Swan Shakespeare Advanced Series, King Lear; Longman; 1991.

Bradford, Richard; Stylistics The New Critical Idiom; London and New York; 1997.

Bradley, Macheth A. C.; Shakespeare Tragedy. Lecturer on Hawlet, Othello, King Lear; Macmilla; Palgrame.

Blake, N. F; The Language of Shakespear; Macmillan : Palgrame; 1995.

Cambridge Advanced Learner Dictionary.

Casey, Francis; King Lear by Shakespeare; The Macmillan Press; 1986.

Cruse; Meaning in Language An Introduction to Semantics and Pragmatics.

Cruse, Alan; Meaning in Language, An Introduction to Semantics and Pragmatics Second Edition; Oxford University Press; Oxford; 2004.

Djoyosuroto, Kinaryali; Filsafat Bahasa; Yogyakarta; Pustaka Book; 2007.

Endraswara, Suwardi; Metode Penelitian Sastra; Yoyakarta; 2011.

Fromkin, Victoria and Robert Rodman; An Introduction to Language; Harcort Brace College; 1998.

Gill, Richard; Mastering Shakespeare; 1998.

Hawkes, Terence; William Shakespeare King Lear; London; 1985.

Indrawan, Made Iwan; Sociolinguistics, The Study of Societies Languages; Graha IImu; 2010.

Kaelan; Filsafat Bahasa Semiotika dan Hermeneutika; Yogyakarta; Paradigma; 2009

Kenworthy, Joanne; Language in Action, An Introduction to Modern Linguistics; Longman; 1994

Kreider, Charles W; Introducing English Semantics. 
Kridalaksana, Harimurti; Kamus Linguistik; Jakarta; Gramedia; 2008.

Lebron, Malcolm; Mastering the Language of Literature; Macmillan Palgrave; 2004.

Marsh, Nicholas; Analysing Texts Shakespeare Tragedies; St. Martin Press; 1998.

McDougal, Littell; Literature; New York; Evanston; 1989.

Mc Evoy, Sean; Shakespeare The Basics; London and New York; 2000.

Pradopo, Rachmat Djoko; Beberapa Teori Sastra, Metode Kritik dan Penerapannya;

Yoyakarta; Pustaka Pelajar; 2011.

Richards, Jack C., John Platt and Heidi Platt; Dictionary of Language Teaching and Applied Linguistics; 1997.

Ryan , Kiernan; Shakespeare : Texts and Contexts; The Open University; Macmillan; 2000.

Saced, John I; Semantics Second Edition; Blackwell Publishing; 2004.

Samekto; Ikhtisar Sejarah Kesusasteraan Inggris; Jakarta; Gramedia; 1985.

Semi, M. Atar; Metode Penelitian Sastra; Bandung; Angkasa; 1990.

Sipmson, Paul; Routledge Taylor and Francis; Stylistics, A Resources Book for Students; London and New York; 2004.

Shakespeare, William; Critical Essays on King Lear; Longman Literature Guide.

Tarigan, Guntur; Pengajaran Gaya Bahasa; Bandung; Angkasa; 2009.

The New Book of Knowledge; 2003.

Todd, Loreto; An Introduction to Linguistics; Longman Youth; 1987.

Toolan, Michael; Language, Text and Context; 1992.

Wales, Katie; A Dictionary of Stylistics; New York; Longman; 1989.

Walts, Cedric; Wordsworth Classics King Lear, William Shakespeare; Britain; 2004.

Widdowson, H. G; Stylistics and The Teaching of Literature; Longman; 1988.

www.shmoop.com/king-lear/symbolism-imagery.html

http://www.enotes.com/king-lear/q-and-a/king-lear-what-examples-personificationcan-you-313319\#answer-area

http://ivythesis.typepad.com/term_paper_topics/2008/03/thesis-abstract.html http://www.shmoop.com/king-lear/themes.html

http://www.slideshare.net/jukpelto/qualitative-research-methods-presentation737683 